\title{
THE
}

$10-21-2013$

\section{Geodynamic Evolution of a Forearc Rift in the Southernmost \\ Mariana Arc}

Julia M. Ribeiro

Robert J. Stern

Fernando Martinez

Osamu Ishizuka

Susan G. Merle

See next page for additional authors

Follow this and additional works at: https://digitalcommons.uri.edu/gsofacpubs

The University of Rhode Island Faculty have made this article openly available.

Please let us know how Open Access to this research benefits you.

This is a pre-publication author manuscript of the final, published article.

Terms of Use

This article is made available under the terms and conditions applicable towards Open Access Policy Articles, as set forth in our Terms of Use.

\section{Citation/Publisher Attribution}

Ribeiro, Julia M., et al. "Geodynamic Evolution of a Forearc Rift in the Southernmost Mariana Arc." Island $\operatorname{Arc} 22.4$ (2013): 453-476.

Available at: http://dx.doi.org/10.1111/iar.12039

This Article is brought to you for free and open access by the Graduate School of Oceanography at DigitalCommons@URI. It has been accepted for inclusion in Graduate School of Oceanography Faculty Publications by an authorized administrator of DigitalCommons@URI. For more information, please contact digitalcommons-group@uri.edu. 


\section{Authors}

Julia M. Ribeiro, Robert J. Stern, Fernando Martinez, Osamu Ishizuka, Susan G. Merle, Katherine Kelley, Elizabeth Y. Anthony, Minghua Ren, Yasuhiko Ohara, Mark Reagan, Guillaume Girard, and Sherman Bloomer 


\section{Geodynamic evolution of a forearc rift in the southernmost Mariana Arc}

3 Julia M. Ribeiro ${ }^{1}$, Robert J. Stern ${ }^{1}$, Fernando Martinez ${ }^{2}$, Osamu Ishizuka ${ }^{3,10}$, Susan G.

4 Merle $^{4}$, Katherine Kelley ${ }^{5}$, Elizabeth Y. Anthony ${ }^{6}$, Minghua Ren ${ }^{6}$, Yasuhiko Ohara ${ }^{7,}$,

$5 \quad$ Mark Reagan $^{8}$, Guillaume Girard ${ }^{8}$, Sherman Bloomer ${ }^{9}$

6

$7{ }^{1}$ Geosciences Department, University of Texas at Dallas, 800 W. Campbell Rd. Richardson, TX

8 75083-0688, USA

$9{ }^{2}$ Hawai'i Institute of Geophysics and Planetology, SOEST, University of Hawai'i at Manoa, 680

10 East-West Rd, POST 602, Honolulu, HI 96822 USA

$11{ }^{3}$ Geological Survey of Japan, AIST, Central 7, 1-1-1 Higashi, Tsukuba, Ibaraki 305-8567, Japan

$12{ }^{4}$ Oregon State University, NOAA Vents Program, 2115 SE Oregon State University Dr.,

13 Newport, OR 97365, USA

$14{ }^{5}$ Graduate School of Oceanography, University of Rhode Island, Narragansett Bay Campus,

15 Narragansett, RI 02882, USA

$16{ }^{6}$ University of Texas at El Paso, Department of Geological Sciences, 500 West University

17 Avenue, El Paso, TX 79968, USA

$18{ }^{7}$ Hydrographic and Oceanographic Department of Japan, 2-5-18 Aomi, Koto-ku, Tokyo 135-

19 0064, Japan

$20{ }^{8}$ Department of Geosciences, University of Iowa, 10 Glendale Court, Iowa City, IA 52242, USA

$21{ }^{9}$ Geosciences Department, Oregon State University, 128 Kidder Hall, Corvallis, OR 97331, USA

$22{ }^{10}$ Japan Agency for Marine-Earth Science and Technology, Natsushima 2-15, Yokosuka 237-

23 0061, Japan 


\section{Abstract}

27 The southernmost Mariana forearc stretched to accommodate opening of the Mariana Trough 28 backarc basin in late Neogene time, erupting basalts now exposed in the SE Mariana Forearc Rift 29 (SEMFR) $3.7-2.7 \mathrm{Ma}$ ago. Today, SEMFR is a broad zone of extension that formed on 30 hydrated, forearc lithosphere and overlies the shallow subducting slab (slab depth $\leq 30-50 \mathrm{~km}$ ).

31 It comprises NW-SE trending subparallel deeps, $3-16 \mathrm{~km}$ wide, that can be traced $\geq \sim 30 \mathrm{~km}$ 32 from the trench almost to the backarc spreading center, the Malaguana-Gadao Ridge (MGR).

33 While forearcs are usually underlain by serpentinized harzburgites too cold to melt, SEMFR crust

34 is mostly composed of Pliocene, low-K basaltic to basaltic andesite lavas that are compositionally

35 similar to arc lavas and backarc basin (BAB) lavas, and thus defines a forearc region that recently 36 witnessed abundant igneous activity in the form of seafloor spreading. SEMFR igneous rocks 37 have low $\mathrm{Na}_{8}, \mathrm{Ti}_{8}$, and $\mathrm{Fe}_{8}$, consistent with extensive melting, at $\sim 23 \pm 6.6 \mathrm{~km}$ depth and $1239 \pm$ $3840^{\circ} \mathrm{C}$, by adiabatic decompression of depleted asthenospheric mantle metasomatized by slab-

39 derived fluids. Stretching of pre-existing forearc lithosphere allowed BAB-like mantle to flow

40 along SEMFR and melt, forming new oceanic crust. Melts interacted with preexisting forearc

41 lithosphere during ascent. SEMFR is no longer magmatically active and post-magmatic tectonic 42 activity dominates the rift.

44 KEYWORDS: forearc rift, seafloor spreading, Mariana arc, subduction zone 


\section{1. Introduction}

$47 \quad$ Forearcs are cold regions above subduction zones that lie between the trench and the magmatic

48 arc. They can be accretionary or non-accretionary depending on the amount of sediments carried

49 into the trench (Lallemand, 2001, Stern, 2002). Non-accretionary forearcs, such as that of the

50 Marianas, are of special interest as they preserve a record of the first lavas erupted in association

51 with subduction initiation (Ishizuka et al., 2011, Reagan et al., 2010, Stern \& Bloomer, 1992).

52 Forearc lithosphere is underlain by the cold, subducting plate that releases its hydrous fluids into

53 the upper mantle wedge, resulting in exceptionally cold $\left(<400^{\circ} \mathrm{C}\right.$; Hulme et al., 2010) and

54 serpentinized mantle lithosphere that rarely melts (Hyndman \& Peacock, 2003, Van Keken et al.,

55 2002, Wada et al., 2011). The occurrence of cold, serpentinized forearc mantle beneath the

56 Mariana forearc is demonstrated by eruption of serpentinite mud volcanoes (Hulme et al., 2010,

57 Mottl et al., 2004, Savov et al., 2007, Savov et al., 2005, Wheat et al., 2008) and serpentinized

58 peridotite outcroppings on the inner trench slope (Bloomer \& Hawkins, 1983, Ohara \& Ishii,

59 1998). Serpentinized mantle beneath the forearc has also been imaged by geophysical surveys

60 (Tibi et al., 2008). Ultramafic rocks from the upper mantle wedge found as clasts in mud

61 volcanoes and on the inner trench slope mostly consist of harzburgite, residues of mantle melting

62 (Parkinson \& Pearce, 1998, Savov et al., 2007, Savov et al., 2005) that are chemically distinct

63 from the more fertile, backarc basin (BAB) peridotites (Ohara et al., 2002). Such highly depleted,

64 forearc mantle can melt in association with early-arc volcanism to generate boninites (Reagan et

65 al., 2010, Stern \& Bloomer, 1992). Decompression melting of more fertile mantle to form

66 tholeiitic basalts near the trench also has been documented during the first stage of subduction

67 initiation. These lavas have MORB-like compositions and have been termed forearc basalts 
68 (FABs) reflecting their subduction-related origin and location in modern forearcs (Reagan et al.,

69 2010).

71 In the Izu-Bonin-Mariana (IBM) intraoceanic system, most forearc lavas are Eocene - Oligocene

72 in age and younger forearc lavas are unusual (Ishizuka et al., 2011, Reagan et al., 2010, Stern \&

73 Bloomer, 1992). Here, we document the first record of Pliocene forearc lavas from the

74 southernmost Mariana convergent margin, indicating that the mantle can melt beneath forearcs

75 long after subduction initiation. These low-K lavas are tholeiitic basalts generated from BAB-like

76 asthenospheric mantle during seafloor spreading in the Southeast Mariana Forearc Rift (SEMFR),

77 which is a broad zone of deformation ( $40 \mathrm{~km}$ wide and $\sim 60 \mathrm{~km}$ long), extending from the

78 trench to the Fina-Nagu arc Volcanic Chain (FNVC). SEMFR today overlies a shallow

79 subducting Pacific slab ( $\leq 50-100$ km deep; Becker, 2005).

81 This paper presents a first report on the geology and tectonic evolution of the SEMFR. We

82 present bathymetry, summarize the results of bottom traverses, and provide petrologic, major

83 element geochemical data and ${ }^{40} \mathrm{Ar} /{ }^{39} \mathrm{Ar}$ ages of igneous rocks sampled during two JAMSTEC

84 research cruises. These data are used to characterize SEMFR lavas and to address when, where,

85 and how SEMFR lavas were generated, and to determine sources of the magmas, and conditions

86 of melting. Addressing these issues helps us better understand how such melts were produced in a

87 cold forearc, and allows us to develop a geodynamic model to constrain the geodynamic

88 evolution of the S. Mariana forearc. In this manuscript, we show that SEMFR lavas have BAB-

89 like geochemical and petrographic features; and opening of the Southernmost Mariana Trough

90 allowed adiabatic decompression melting of BAB-like asthenospheric mantle in the forearc to

91 produce SEMFR lavas 3.7 - 2.7 Ma ago. 


\section{2. Geodynamic setting}

94 The Mariana intraoceanic arc system is the southern third of the IBM convergent margin. It is

95 generally associated with a sediment-starved forearc $\sim 200 \mathrm{~km}$ wide (Fryer et al., 2003, Kato et

96 al., 2003), submarine and subaerial volcanoes of the active magmatic arc (Baker et al., 2008), and

97 a BAB with a spreading axis that generally lies $\sim 250-300 \mathrm{~km}$ from the trench (Stern et al.,

98 2003). Mariana geodynamic evolution was influenced by collisions with buoyant oceanic

99 plateaus (Ogasawara Plateau in the north and Caroline Ridge in the south). These resisted

100 subduction, stimulating backarc extension to open the Mariana Trough between the collisions

101 (Wallace et al., 2005).

102

103 IBM mostly trends N-S but the southernmost Mariana convergent margin $\left(13^{\circ} 10^{\prime} \mathrm{N}-11^{\circ} \mathrm{N}\right)$

104 bends to E-W (Fig. 1A ; Bird, 2003). This region is deforming rapidly (Kato et al., 2003,

105 Martinez et al., 2000), accompanied by abundant igneous activity. Here, the Mariana Trench

106 reaches the deepest point on Earth at the Challenger Deep (10994 m; Gardner \& Armstrong,

107 2011), and Pacific-Philippine Sea plate convergence is approximately orthogonal to the trench

108 (Bird, 2003). The tectonic evolution of the southernmost Mariana arc began with the Late

109 Miocene collision of the Caroline Ridge, which pinned the Yap arc and allowed the southern

110 Mariana Trough to open, sculpting the southern termination of the arc (Miller et al., 2006b). The

111 southernmost Mariana magmatic arc is poorly developed and entirely submarine, contrasting with

112 the large, often subaerial, arc volcanoes to the north. The arc magmatic front almost intersects the

113 southern end of the BAB spreading center south of $13^{\circ} \mathrm{N}$ (Fig. 1B; Fryer et al., 2003). These

114 features are about $100-150 \mathrm{~km}$ from the trench, whereas to the north the BAB spreading axis 
115 lies $\sim 250-300 \mathrm{~km}$ from the trench and is separated from the magmatic arc by $50-100 \mathrm{~km}$ (Fryer

116 et al., 1998, Stern et al., 2003). The magmatic arc appears to have been reorganized recently, as

117 evidenced by a complex bathymetric high with multiple nested calderas - an inferred paleo-arc

118 (the Fina-Nagu Volcanic Chain in Fig. 1B) where no hydrothermal activity was observed (Baker

119 et al., 2008) and calderas are covered with sediments (Fig. 1C) - SE of and parallel to the modern

120 magmatic arc (e.g. Toto caldera). The southern Mariana Trough has a well-defined spreading

121 ridge, the Malaguana-Gadao Ridge (MGR), with a well-developed magma chamber and several

122 hydrothermal vents (Baker et al., 2008, Becker et al., 2010, Kakegawa et al., 2008). Because the

123 subducted Pacific plate lies $100 \mathrm{~km}$ beneath it, the MGR melt source region captures hydrous

124 fluids usually released beneath arc volcanoes, enhancing mantle melting and resulting in an

125 inflated ridge morphology that is unusually robust for the Mariana Trough backarc basin, in spite

126 of an intermediate spreading rate $(<65 \mathrm{~mm} / \mathrm{yr}$; Becker et al., 2010, Fryer et al., 1998, Martinez et

127 al., 2000). More rapid extension along the MGR might also enhance decompression melting

128 (Becker et al., 2010).

130 The southernmost Mariana convergent margin is underthrust by a narrow slab of Pacific plate

131 (traceable to $~ 250 \mathrm{~km}$ depth; Gvirtzman \& Stern, 2004), torn N-S at 144 ${ }^{\circ} 15^{\prime}$ E (Fryer et al.,

132 1998, Gvirtzman \& Stern, 2004). Analogue experiments show that short, narrow subducted slabs

133 trigger toroidal (around the slab edge) and poloidal (underneath the slab tip) asthenospheric

134 mantle flows that generate rapid slab rollback and trench retreat relative to the upper plate

135 (Funiciello et al., 2003, Funiciello et al., 2006, Schellart et al., 2007). These conditions lead to

136 weak coupling of the subducting plate with the overriding plate, stimulating rapid deformation of

137 the overriding plate (i.e., the southern Mariana Trough) and may be responsible for the very 
138 narrow forearc that defines the southern Mariana margin west of the W. Santa Rosa Bank Fault

139 (Fig. 1B, Gvirtzman \& Stern, 2004). The unusual tectonic situation of the southernmost Mariana

140 convergent margin has also affected magmagenesis. Sub-forearc mantle usually is too cold to

141 melt (Van Keken et al., 2002), so that slab-derived fluids only lead to serpentinization (Hyndman

142 \& Peacock, 2003, Wada et al., 2011). Instead, the dynamic tectonic setting of the southern

143 Marianas results in mantle melting much closer to the trench than is normally observed.

\section{3. Geology and morphology of the Southeast Mariana Forearc Rift}

146 Most of the IBM convergent margin is underlain by lithosphere that formed after subduction

147 began $52 \mathrm{Ma}$ (Ishizuka et al., 2011, Reagan et al., 2010). In the southernmost Marianas, Eocene

148 forearc lithosphere was stretched in late Neogene time to accommodate opening of the Mariana

149 Trough BAB; part of this extension is localized along the SEMFR (Martinez \& Stern, 2009). The

150 morphological expression of the SEMFR is apparent over a region $\sim 40 \mathrm{~km}$ wide and at least 60

$151 \mathrm{~km}$ long (Supporting Information Table S1.2). SEMFR is composed of broad southeast-trending

152 deeps and ridges (Fig. 1B), each 50 to $60 \mathrm{~km}$ long and 3 to $16 \mathrm{~km}$ wide, which opened nearly

153 parallel to the trench axis. These rifts can be traced from the Mariana Trench almost to the FNVC

154 (Fig. S1.1 in Supporting Information S1). Eastward, the SEMFR is bounded by a N-S fault, the

155 W. Santa Rosa Bank fault (WSRBF, Fig. 1B; Fryer et al., 2003), which separates thick crust of

156 the broad Eocene forearc to the north and east (including that beneath Santa Rosa Bank) from the

157 deeper and narrower forearc of the S. Marianas - including SEMFR - to the west. WSRBF also

158 appears to overlie a tear in the subducted slab (Fryer et al., 2003, Gvirtzman \& Stern, 2004). The

159 WSRBF is taken to be the eastern boundary of the SEMFR because it does not have the same 
160 NNE-SSW trend as the three SEMFR deeps (Fig. 1B), and the forearc is significantly older to the

161 east (Reagan et al., 2010). SEMFR overlies the shallow part of the slab $(\leq 30-100 \mathrm{~km}$ deep,

162 Becker, 2005) and is situated in a region with numerous shallow (crustal) earthquakes, (Martinez

163 \& Stern, 2009) signifying active deformation.

165 We studied SEMFR by interpreting swathmapped bathymetry and previously published HMR-1

166 sonar backscatter imagery (Martinez et al., 2000). The region is characterized by high sonar

167 backscatter, indicating little sedimentary cover (Fig. 1C). This was confirmed by Shinkai 6500

168 manned submersible and YKDT deep-tow camera / dredge seafloor studies. Table S1.1 in

169 Supporting Information S1 summarizes the position and lithologies encountered during these

170 dives (Fig. 1B). Most dives recovered basalt. In addition, deeper crustal and upper mantle

171 lithologies, e.g. diabase, fine-grained gabbros and deformed peridotites, were recovered near the

172 WSRBF (Supporting Information Fig. S1.7 and S1.8). Similar lithologies are also reported by

173 previous studies of the area (Bloomer \& Hawkins, 1983, Fryer, 1993, Michibayashi et al., 2009,

174 Sato \& Ishii, 2011). Based on relief, the SEMFR can be subdivided along strike into NW, central,

175 and SE sectors. SEMFR relief is ruggedest in the SE sector near the trench, where it is intensely

176 faulted and affected by landsliding, with abundant talus slopes of fragmented basaltic lavas (Fig.

177 2A, C, D and Fig. S1.5 to S1.8 in Supporting Information). The central SEMFR is less faulted,

178 with more outcrops and less talus, but still has many steep talus slopes and faulted lava flows

179 (Fig. S1.9 - S1.10 in Supporting Information). The NW SEMFR, nearest the MGR, has gentler

180 relief, with better-preserved pillow lava outcrops (Fig. 2B, E and Fig. S1.11 - S1.13 in Supporting

181 Information). We did not recover samples of Paleogene forearc crust in the SEMFR, although this

182 is common to the NE and west, indicating that SEMFR is floored by young, tectonized oceanic 
183 crust. Our bottom observations along with the absence of parallel magnetic fabrics in the SEMFR

184 (Martinez et al., 2000) suggest that the SEMFR is no longer a site of active volcanism.

186 Toto caldera and part of the MGR near the NW limit of the SEMFR were studied during ROV

187 Kaiko Dives 163 and 164 (R/V Kairei cruise KR00-03 Leg 2, Fig. 1B). Toto caldera, which may

188 be part of the immature magmatic arc, is mostly covered by talus of fresh lava fragments with a

189 whitish coating, perhaps bacteria or sulfur-rich precipitate (Supporting Information Fig. S1.14),

190 derived from the active Nakayama hydrothermal site (Gamo et al., 2004, Kakegawa et al., 2008).

191 The MGR seafloor is mostly composed of fresh, well-preserved pillow lavas alternating with aa

192 and solidified lava lake (Becker et al., 2010), along with active hydrothermal vents (Supporting

193 Information Fig. S1.15) indicating ongoing magmatic activity. Fig. 1C shows high sonar

194 backscatter for Toto caldera and around the MGR, indicating hard rock (fresh lava) exposures and

195 thin sediments, consistent with seafloor seen in dive videos.

\section{Methods}

198 Igneous rock samples were collected during two cruises YK08-08 Leg 2 (Shinkai 6500 manned 199 submersible dive 1096) in 2008 and YK10-12 (Shinkai 6500 dives 1230, 1235 and Yokosuka

200 deep-tow camera dredge (YKDT) 85, 86, and 88) in 2010. Representative, fresh samples were 201 selected onboard for petrographic and geochemical studies. Information from Kaiko ROV dives

202163 and 164 (R/V Kairei cruise KR00-03 Leg 2 in 2000) is also included. High-resolution videos

203 of the seafloor generated during dives were reviewed during and after the cruises (see Supporting

204 Information S1 for more details). GMT (Smith \& Wessel, 1990, Wessel \& Smith, 1995b, Wessel

205 \& Smith, 1998, Wessel \& Smith, 1995a) was used to compile SEMFR bathymetric data, 
206 including swathmapping results from these cruises and those of Gardner (2006), Gardner (2007)

207 and Gardner (2010). Maps were imported into ArcGIS to generate bathymetric cross sections

208 perpendicular to the strike of SEMFR (Fig. S1.1 in Supporting Information).

210 Igneous rock samples were analyzed, using procedures reported in Supporting Information S2.

211 For major element analyses, fresh sample chips containing as few phenocrysts as possible were

212 hand-picked and powdered in an alumina ball mill. Whole rock chemical analyses for Shinkai

213 dive 1096 samples were carried out on Philips PW1404 X-Ray fluorescence (XRF) spectrometer

214 at the Geological Survey of Japan/AIST. External errors and accuracy are $<2 \%$. Whole rock

215 chemical analyses for other samples were performed at University of Rhode Island by fusion -

216 dissolution of glass beads; and analyses were conducted using a Ultima-C Jobin Yvon Horiba

217 Inductively Coupled Plasma Atomic Emission Spectroscopy (ICP-AES) at Boston University.

218 Glass beads were generated by melting $400 \pm 5 \mathrm{mg}$ of lithium metaborate $\left(\mathrm{LiBO}_{4}\right)$ flux with 100

$219 \pm 5 \mathrm{mg}$ of ignited sample powder at $1050^{\circ} \mathrm{C}$ for $10 \mathrm{~min}$. Molten beads were dissolved in $5 \%$ nitric

220 acid to achieve a final dilution factor of $~ 4000$ (Kelley et al., 2003). Calibration curves for ICP-

221 AES data yield $\mathrm{r}^{2} \geq 0.999$, reproducibility of replicate analyses are $\leq 3 \%$ rsd for each element, 222 and major element oxides sum to $99 \pm 1 \mathrm{wt} \%$. Replicates of samples analyzed by ICP-AES and

223 XRF yield averaged reproducibility < 4\% rsd for each element. Results are reported in Table 1.

224 For mineralogical chemistry analyses, polished thin sections were prepared for 16 samples. These 225 were analyzed using the Cameca SX-50 electron microprobe at University of Texas at El Paso.

226 Multiple point analyses give a mean value with $1 \sigma$ precision $\leq 1 \mathrm{wt} \%$ for each selected mineral. 
228 Four samples were dated by step-heating ${ }^{40} \mathrm{Ar}-{ }^{39} \mathrm{Ar}$ at the Geological Survey of Japan/AIST on a

229 VG Isotech VG3600 noble gas mass spectrometer fitted with a BALZERS electron multiplier.

230 Further details of procedures are reported in Supporting Information S2.

\section{Results}

\subsection{Rock description:}

234 Here we outline the principal petrographic and mineralogical features of igneous rocks sampled 235 from the SEMFR, Toto caldera and MGR. Method for sample description is reported in

236 Supporting Information S3 and detailed sample descriptions are in Supporting Information S4.

237 SEMFR lavas are mostly aphyric ( $<1 \%$ phenocrysts) and sparsely phyric ( $1-5 \%$ phenocrysts)

238 basalts and basaltic andesites, indicating eruption at near-liquidus temperatures. These are

239 microporphyritic pillows or massive flows, with thin, microcrystallite-rich glassy rims $(1-11 \mathrm{~mm}$

240 of fresh, translucent to dark brown glass), thin $(\leq 1 \mathrm{~mm})$ Mn coat, and negligible alteration (Fig.

241 3). Pillow lavas are vesicular despite being collected at $\sim 6000-3000 \mathrm{~m}$, indicating that these

242 magmas contained significant volatiles. In contrast, basalt massive lava flows are more crystalline

243 and less vesicular. Embayed phenocrysts indicate disequilibrium, perhaps due to magma mixing.

244 Pillowed lavas sampled in the NW (YKDT-88) contain larger crystals ( $\geq 0.5 \mathrm{~mm}$ ) of

245 clinopyroxene and olivine set in a finely microcrystalline olivine-rich groundmass (Fig. 3C).

246 Similar olivine-rich lavas were not sampled elsewhere in the SEMFR. Diabase and fine-grained

247 gabbros were also recovered near the WSRB fault (Shinkai 6500 dive 1235; Fig. 3B, D). These

248 might represent the lower crust of SEMFR (dike complex and gabbro layer). Pillow lavas from

249 MGR are very fresh, with translucent glassy rinds. Lavas are vesicular, cryptocrystalline

250 andesites with a glassy groundmass and $<1 \%$ plagioclase microlites. Lava flows from Toto 
251 caldera are vesicular, sparsely phyric to aphyric, fine-grained to cryptocrystalline basaltic 252 andesites.

\subsection{Major element and mineral compositions:}

255 SEMFR lavas are fresh basalts and basaltic andesites, with 50.4 to $57.0 \mathrm{wt} \% \mathrm{SiO}_{2}$ (data reported 256 are adjusted to $100 \%$ total on an anhydrous basis, Fig. 4A). In terms of normative compositions, 257 all lavas are quartz tholeiites. These define a low- $\mathrm{K}$ to medium- $\mathrm{K}$ suite, with $\mathrm{K}_{2} \mathrm{O}<1 \mathrm{wt} \%$. Lava 258 compositions cluster along the tholeiitic - calc-alkaline boundary on a plot of $\mathrm{FeO} * / \mathrm{MgO}$ vs.

$259 \mathrm{SiO}_{2}$ (Fig. 4B; Miyashiro, 1974), or along the medium-Fe / low-Fe boundary (Arculus, 2003).

260 Lavas recovered during Shinkai 6500 dive 1096 and 1230 and YKDT-86 and -88 are relatively

261 primitive, with whole-rock $\mathrm{Mg} \#(=$ atomic $\mathrm{Mg} * 100 /(\mathrm{Mg}+\mathrm{Fe}))>60$, Fig. 4C). Other SEMFR

262 samples are significantly more fractionated, with $\mathrm{Mg} \#=41-60$. Composition of SEMFR lavas is

263 reported in Table 1. MGR and Toto caldera lavas are mostly andesites $\left(\mathrm{SiO}_{2}=55.1-61.7 \mathrm{wt} \%\right.$,

264 with $\mathrm{K}_{2} \mathrm{O}<0.5 \mathrm{wt} \%$ and $\left.\mathrm{Mg} \#=33-53\right)$. None of the studied lavas are boninitic $(\mathrm{MgO}>8 \mathrm{wt} \%$,

$265 \mathrm{SiO}_{2}>52 \mathrm{wt} \%, \mathrm{TiO}_{2}<0.5 \mathrm{wt} \% ;$ Le Bas, 2000). Toto caldera lavas plot within the compositional

266 field of southernmost Mariana volcanic arc lavas (SMA: $13^{\circ} 10^{\prime} \mathrm{N}-11^{\circ} \mathrm{N}$, Kakegawa et al., 2008,

267 Stern et al., 2013), suggesting that Toto caldera belongs to the S. Mariana arc volcanoes (SMA).

268 Toto caldera samples also cluster along the tholeiitic - calc-alkaline boundary. In contrast, MGR

269 lavas are tholeiitic (medium-Fe to high-Fe) basaltic andesites and andesites (Kakegawa et al.,

270 2008, Pearce et al., 2005 ; Fig. 4A, B). The Fe enrichment of the MGR lavas (Fig. 4B) suggests

271 that their parental magmas contain less water, inhibiting early crystallization of Fe-oxides. In Fig.

272 4A, MGR lavas do not plot along the SEMFR fractionation trend, and their similar $\mathrm{K}_{2} \mathrm{O}$ content

273 suggests that MGR and SEMFR lavas interacted with similar arc-like slab-derived fluids. FABs 
274 (Reagan et al., 2010) are low-K to medium-K basalt to basaltic andesites that plot within the

275 tholeiitic and calc-alkaline fields (Fig. 4B, C); and SEMFR plot along the FAB fractional trend

276 (Fig. 4C, D). All lavas from the southernmost Marianas suggest fractionation controlled by

277 plagioclase, clinopyroxene \pm olivine crystallization trend (Fig. 4C, F).

279 SEMFR basalts and basaltic andesites contain olivine, clinopyroxene, and plagioclase. Results for 280 representative mineral composition are listed in Supporting Information Tables S4.1 to S4.4 and 281 summarized in Table 2. Mineral compositions correlate with whole rock chemical compositions 282 (Fig. 5A, B and Supporting Information S5). Near-primitive (Mg\# > 60), olivine-rich SEMFR 283 lavas (Shinkai dive 1096, upper series and YKDT-88) contain Mg-rich olivines (Fo86-88) in 284 equilibrium with $\mathrm{Mg}$-rich clinopyroxene $(\mathrm{Mg \#}=83-91)$ and anorthitic plagioclase $(\mathrm{An} \geq 80)$. In 285 contrast, fractionated $(\mathrm{Mg \#} \leq 60)$ lavas have Fe-rich olivine $\left(\mathrm{Fo}_{75-84}\right)$ coexisting with two kinds of 286 clinopyroxene (endiopside - diopside with $\mathrm{Mg} \# \geq 80$ and augite with $\mathrm{Mg \#}<80$ ) and plagioclase 287 (An $\geq 80$ and $A n<80$ ). Reverse and oscillatory zoning is only observed in more fractionated 288 plagioclase (An $<80$ in the core), suggesting magma mixing perhaps in a magmatic reservoir.

289 Fine-grained gabbro and diabase have Mg-rich clinopyroxenes (Mg\# $\geq 60)$ coexisting with more 290 albitic plagioclase (An $\leq 70)$. The mineral composition of Toto caldera lavas and MGR lavas are 291 within the compositional range of SEMFR lavas. Occurrence of two mineral compositional 292 groups in Toto and MGR lavas, without significant compositional overlap, strongly suggests 293 magma mixing (Supporting Information S4.2 and Fig. S4.1).

295 Olivine xenocrysts $(\geq 0.5 \mathrm{~mm})$ enclosing chromium spinel are common in primitive lavas (Fig. 296 3C, 5E). Olivine xenocrysts have higher Fo contents (Fo89-92 core and Fo87-97 rim) than do the 297 olivine phenocrysts (Fo86-88, Table S4.3 and Fig. S4.1 in Supporting Information) in their host 
298 basalts. Olivine xenocrysts host chromium spinel with $\mathrm{Cr} \#(=100 \times \mathrm{Cr} /(\mathrm{Cr}+\mathrm{Al}))=47-73$. The

299 olivine - spinel assemblages plot in the mantle array of Arai (1994) and they are similar to those

300 of the SE Mariana forearc mantle peridotite (Cr\# > 50 and Fo90-92, Ohara \& Ishii, 1998),

301 suggesting that these xenocrysts are samples of forearc mantle (Fig. 5C).

302

303

5.3. ${ }^{40}$ Ar- ${ }^{39}$ Ar ages:

304 Four SEMFR samples (2 samples from Shinkai 6500 dive 1096, 1 sample each from Shinkai

3056500 dive 1230 and YKDT-88) were dated by step-heating ${ }^{40} \mathrm{Ar}-{ }^{39} \mathrm{Ar}$ (Fig. 6 and Table 1). Initial

$306{ }^{40} \mathrm{Ar} /{ }^{36} \mathrm{Ar}$ for these samples $(290-295)$ is nearly atmospheric $\left({ }^{40} \mathrm{Ar} /{ }^{36} \mathrm{Ar}\right.$ atmosphere $\left.=298.6\right)$,

307 indicating that negligible radiogenic ${ }^{40} \mathrm{Ar}$ was inherited. Dated samples from dive 1096 samples

308 include one from each of the lower (1096-R2) and upper series (1096-R16) lavas. These gave

309 indistinguishable plateau ages of $3.5 \pm 0.4 \mathrm{Ma}$ (lower series 1096-R2) and $3.7 \pm 0.3 \mathrm{Ma}$ (upper

310 series 1096-R16). Shinkai dive 1230 and YKDT-88 gave slightly younger ages, respectively of

$3112.8 \pm 0.5 \mathrm{Ma}$ and $2.7 \pm 0.3 \mathrm{Ma} . \mathrm{SEMFR}{ }^{40} \mathrm{Ar}-{ }^{39} \mathrm{Ar}$ ages indicate that seafloor spreading occurred

312 in Pliocene time (Fig. 1B), and suggests that SEMFR seafloor youngs toward the MGR.

\section{6. Discussion}

\subsection{Genesis of SEMFR lavas:}

316 Compositions of lavas and their minerals record the conditions of magma genesis and evolution;

317 and from this, important tectonic information can be gleaned (e.g. Klein \& Langmuir, 1987).

318 Incompatible elements such as $\mathrm{K}_{2} \mathrm{O}, \mathrm{Na}_{2} \mathrm{O}$ and $\mathrm{TiO}_{2}$ are concentrated in the melt as mantle

319 melting or crystal fractionation proceeds. The first melt fraction is enriched in these elements and 
320 so concentrations anti-corrrelate with fraction of melting, or "F" (Kelley et al., 2006, Kelley et

321 al., 2010, Klein \& Langmuir, 1987, Taylor \& Martinez, 2003). In addition, $\mathrm{K}_{2} \mathrm{O}$ contents in

322 convergent margin magma sources are strongly affected by subduction-related metasomatism

323 (e.g. K-h relationship, Dickinson, 1975, Kimura \& Stern, 2008), therefore this element is

324 generally not used to monitor $\mathrm{F}$. $\mathrm{FeO}$ contents in basalts also contain petrogenetic information. In

325 basaltic systems, deeper melts are progressively enriched in iron (Klein \& Langmuir, 1987).

326 Therefore, the $\mathrm{Na}_{2} \mathrm{O}, \mathrm{TiO}_{2}$ and $\mathrm{FeO}$ contents of lavas are good proxies for the degree and depth of

327 melting. However, estimating the extent and depth of partial melting requires primitive lavas with

328 compositions in equilibrium with their mantle source; consequently, $\mathrm{Na}_{2} \mathrm{O}, \mathrm{TiO}_{2}$ and $\mathrm{FeO}$

329 contents are commonly corrected for olivine fractionation in order to infer their $\mathrm{Na}_{8}, \mathrm{Ti}_{8}$ and $\mathrm{Fe}_{8}$

330 contents $\left(\mathrm{Na}_{2} \mathrm{O}, \mathrm{TiO}_{2}\right.$ and $\mathrm{FeO}$ contents calculated at $\left.\mathrm{MgO}=8 \mathrm{wt} \%\right)$. The $\mathrm{Na}_{8}$ of N-MORBs anti-

331 correlates with $\mathrm{Fe}_{8}$, indicating that melting is greater if it begins deeper (Fig. 7A; Arevalo Jr. \&

332 McDonough, 2010, Klein \& Langmuir, 1987). Subduction-related melting is somewhat different

333 because melting extents are enhanced by water (Gribble et al., 1996, Kelley et al., 2006, Taylor \&

334 Martinez, 2003). BAB magma sources often are affected by subducted water and are

335 characterized by more melting at shallower depth than MORBs, so that $\mathrm{Na}_{8}$ increases with $\mathrm{Fe}_{8}$

336 (Fig. 7A; Kelley et al., 2006, Taylor \& Martinez, 2003). BAB and arc lavas have distinct

337 geochemical signatures (Fig. 7), resulting from elements dissolved in fluids derived from the

338 subducting slab that are involved in magma genesis. Arc lavas have lower $\mathrm{Na}_{8}$ and $\mathrm{Ti}_{8}$ contents at

339 higher $\mathrm{K}_{2} \mathrm{O} / \mathrm{TiO}_{2}$ and $\mathrm{Fe}_{8}$ content because they formed by high degrees of melting at greater

340 depths in the presence of slab-derived fluids. In contrast, $\mathrm{BAB}$ lavas have higher $\mathrm{Na}_{8}$ and $\mathrm{Ti}_{8}$

341 contents at lower $\mathrm{K}_{2} \mathrm{O} / \mathrm{TiO}_{2}$ and $\mathrm{Fe}_{8}$ content, as they were generated at shallower depth by

342 adiabatic mantle decompression, with less involvement of slab-derived fluids. 
344 To investigate SEMFR magmagenesis (i.e. whether SEMFR lavas were produced in a BAB-like

345 and / or in a arc-like magmagenetic settings), we calculated $\mathrm{Na}_{8}, \mathrm{Ti}_{8}$ and $\mathrm{Fe}_{8}$ contents for these

346 lavas. Plots of $\mathrm{Al}_{2} \mathrm{O}_{3}, \mathrm{CaO}$ and $\mathrm{FeO} *$ against $\mathrm{MgO}$ (Fig. 4D-F) show that the kinks in $\mathrm{Al}_{2} \mathrm{O}_{3}$ and

$347 \mathrm{CaO}$, indicating the beginning of plagioclase and clinopyroxene crystallization, are respectively

348 observed at $\mathrm{MgO}=6 \mathrm{wt} \%$ and at $\mathrm{MgO} \sim 7 \mathrm{wt} \%$. Therefore, data were filtered to exclude highly

349 fractionated samples with $\mathrm{MgO}<7 \mathrm{wt} \%$ that crystallized olivine, clinopyroxene and plagioclase

350 on their LLD (Fig. 4D-F), following the method described in Kelley et al. (2006) and Kelley et al.

351 (2010). The least fractionated samples with 7 - $8 \mathrm{wt} \% \mathrm{MgO}$, which fractionated olivine only (Fig.

352 4D-F), were then corrected to $\mathrm{MgO}=8 \mathrm{wt} \%$ using the equations of Klein and Langmuir (1987)

353 for $\mathrm{Na}_{8}$ and $\mathrm{Fe}_{8}$, and Taylor and Martinez (2003) for $\mathrm{Ti}_{8}$. These are listed in Table 1 (mean

354 SEMFR Na $=1.99 \pm 0.40$ wt $\%$ (1 std. dev.); mean $\mathrm{Ti}_{8}=0.60 \pm 0.11$ wt $\%$; mean $\mathrm{Fe}_{8}=6.91 \pm$

$3550.54 \mathrm{wt} \%$ ). The $\mathrm{Na}_{8}, \mathrm{Fe}_{8}$ and $\mathrm{Ti}_{8}$ contents of SEMFR lavas are slightly lower than those

356 observed for N-MORBs (Arevalo Jr. \& McDonough, 2010), indicating higher degrees of mantle

357 melting produced shallower. SEMFR lavas have similar $\mathrm{Ti}_{8}$ and $\mathrm{Na}_{8}$ contents at lower $\mathrm{Fe}_{8}$ than

358 FABs; and they plot in the compositional overlap between Mariana arc lavas and the Mariana

359 BAB lavas, with homogeneous, low $\mathrm{Na}_{8}$ and $\mathrm{Ti}_{8}$ contents varying little with $\mathrm{Fe}_{8}$ content (Fig. 7A

360 - B), suggesting a roughly constant degree and depth of mantle melting. These lavas were

361 produced by extensive melting ( $\geq 15 \%)$ of shallow mantle $(\sim 25 \pm 6.6 \mathrm{~km}$, see section 6.2$)$. The

$362 \mathrm{~K}_{2} \mathrm{O} / \mathrm{TiO}_{2}$ (proxy for the total subduction input; Shen \& Forsyth, 1995) of SEMFR lavas is higher

363 that of FABs and plot between the arc - BAB compositional fields (Fig. 7C - D), well above N-

364 MORBs, further demonstrating a subduction component in SEMFR magma genesis. Only lavas

365 from YKDT-88, collected closest to the FNVC (Fig. 1B), do not plot on the SEMFR

366 compositional field (Fig. 7A-C), with lower $\mathrm{Na}_{8}$ and $\mathrm{Ti}_{8}$ at similar $\mathrm{Fe}_{8}$ contents. $\mathrm{Their}_{\mathrm{Ti}} \mathrm{i}_{8}$ and $\mathrm{Na}_{8}$

367 values are lower than those of Mariana arc lavas (Fig. 7A-C), suggesting that YKDT-88 lavas 
368 were produced by more mantle melting and / or melting of a more depleted mantle source at

369 similar depth compared to other SEMFR magmas.

370

371 The above inference that SEMFR lavas are similar to back-arc basin basalts (BABB) can be

372 checked by examining mineral compositions, because arc basalts and BABBs have distinct An-Fo

373 relationships (Stern, 2010). Arc basalts contain more Fe-rich olivine with more An-rich

374 plagioclase compared to BABB, MORB, and OIB (Ocean Island Basalt, Fig. 8A) because higher

375 water contents in arc magmas delay plagioclase but not olivine crystallization (Kelley et al., 2010,

376 Stern, 2010), resulting in higher $\mathrm{CaO}$ and $\mathrm{FeO}$ contents in the melt when plagioclase starts

377 crystallizing. In contrast, BABBs, formed largely by adiabatic decompression mantle melting,

378 have Fo-An relationships essentially indistinguishable from those of MORB and OIB (Fig. 8A).

379 Accordingly, we can discriminate arc basalts from BABBs based on An and Fo contents of the

380 plagioclase - olivine assemblages. Fig. 8A shows that most SEMFR lavas plot within the BABB

381 compositional field, consistent with observations from $\mathrm{Na}_{8}, \mathrm{Ti}_{8}$, and $\mathrm{Fe}_{8}$ discussed in the previous

382 section. Some samples also plot within the arc compositional field, strongly suggesting that BAB-

383 like (i.e. adiabatic decompression melting) and arc-like (i.e. wet mantle melting) conditions of

384 magmagenesis coexisted beneath SEMFR. We propose that SEMFR magmas formed by adiabatic

385 decompression of fertile asthenospheric mantle (BAB-like mantle) metasomatized by slab-

386 derived fluids, enriching the melt in water and sometimes delaying plagioclase fractionation. 387

6.2.Pressure and temperature of mantle melting:

389 The P-T conditions of mantle melting, recorded by primary melts in equilibrium with the mantle

390 beneath SEMFR, were calculated from major element compositions of primitive basalts with 
$391 \mathrm{MgO} \geq 7$ wt\% (Kelley et al., 2010; Fig. 4D-F) by using the geothermobarometer of Lee et al.

392 (2009), based on $\mathrm{Si}, \mathrm{Mg}$ and water contents of primitive magmas. The estimated P-T conditions

393 are those of the last melt in equilibrium with the mantle or a mean value of the P-T conditions of

394 polybaric, fractional pooled melts recorded along a melting column (Kelley et al., 2010). SEMFR

395 lavas are compositionally similar to BABBs, we therefore used BAB-like oxidation state

$396\left(\mathrm{Fe}^{3+} / \mathrm{Fe}_{\mathrm{T}}=0.17\right)$ and averaged Mariana BAB water content (1.31 wt\%; Gribble et al., 1996,

397 Kelley \& Cottrell, 2009) for SEMFR lavas, $\mathrm{Fe}^{3+} / \mathrm{Fe}_{\mathrm{T}}=0.17$ for Mariana Trough lavas and

$398 \mathrm{Fe}^{3+} / \mathrm{Fe}^{\mathrm{T}}=0.25$ for Mariana arc magmas (Kelley \& Cottrell, 2009). We also used lherzolitic

399 BAB-like mantle source (Fo90; Kelley et al., 2006) to estimate the P-T conditions of SEMFR

400 mantle melting. Primitive lavas of the Mariana Trough and the Mariana arc with analyzed water

401 were filtered for $\mathrm{MgO} \geq 7 \mathrm{wt} \%$ as SEMFR lavas for consistency. SEMFR whole rock

402 compositions indicate melting pressures of $0.5-0.9 \mathrm{GPa}( \pm 0.2 \mathrm{GPa})$ and temperatures of $1217-$

$4031269^{\circ} \mathrm{C}\left( \pm 40^{\circ} \mathrm{C}\right)$, with a mean of $0.7 \pm 0.2 \mathrm{GPa}(\sim 23 \pm 6.6 \mathrm{~km})$ and $1239 \pm 40^{\circ} \mathrm{C}$ (Fig. 8B). This

404 is consistent with melting just above the present subducting slab ( $\leq 30-100 \mathrm{~km}$ depth), although

405 we do not know the position of the subducting slab at 2.7 - 3.7 Ma, when SEMFR melts were

406 generated. Mariana Trough BABBs (Gribble et al., 1996, Kelley \& Cottrell, 2009) have similar P-

407 T conditions of mantle melting $\left(0.7-1.5 \pm 0.2 \mathrm{GPa}, 1214-1359 \pm 40^{\circ} \mathrm{C}\right.$; mean melting depth

$40833 \pm 6.6 \mathrm{~km}$ ). In contrast, Mariana arc lavas (Kelley et al., 2010, Shaw et al., 2008) show higher

409 P-T conditions of mantle melting $\left(1.1-3.0 \pm 0.2 \mathrm{GPa}, 1240-1522 \pm 40^{\circ} \mathrm{C}\right)$. These results

410 suggest that SEMFR lavas and Mariana Trough BABBs were similarly generated by adiabatic

411 decompression of shallow asthenospheric mantle $(\sim 25-30 \pm 6.6 \mathrm{~km})$. In contrast, arc lavas

412 (Kelley \& Cottrell, 2009, Kelley et al., 2010, Shaw et al., 2008) recorded deeper (mean melting

413 depth $\sim 51 \pm 6.6 \mathrm{~km}$ ). and hotter mantle melting conditions (Kelley et al., 2010). This leads to the

414 further deduction that SEMFR lavas formed by BABB-like seafloor spreading at 2.7 to 3.7 Ma. 
417 Investigations of the petrography and geochemistry of SEMFR lavas reveal that i) SEMFR lavas

418 are petrographically and compositionally similar to Mariana Trough BABBs; ii) SEMFR melts

419 interacted with the pre-existing forearc lithosphere and picked up some forearc mantle olivines,

420 indicating rapid ascent; iii) magmatic activity $(2.7-3.7 \mathrm{Ma})$ formed SEMFR oceanic crust by

421 seafloor spreading (no Eocene forearc basement has been recovered from the SEMFR); iv)

422 SEMFR primitive basalts formed by decompression melting at $\sim 23 \mathrm{~km}$ depth and $1239^{\circ} \mathrm{C}$, like

423 that associated with the Mariana Trough backarc basin, suggesting similar formation; and v) lack

424 of evidence for recent igneous and hydrothermal activity, except near MGR and Toto caldera,

425 indicates that the presently-observed NNW-SSE trending relief formed during post-magmatic 426 rifting $(<2.7 \mathrm{Ma})$.

428 SEMFR is a rift with no morphological expression of large arc-like volcanoes, like those of the

429 Mariana arc. SEMFR lavas are vesicular with $\mathrm{K}_{2} \mathrm{O}$ contents (Fig. 4A) and $\mathrm{K}_{2} \mathrm{O} / \mathrm{TiO}_{2}$ ratios that 430 are similar to MGR and other Mariana Trough BAB lavas (Fig. 7C, D). They also have similar P-

431 T conditions of magma genesis, demonstrating that they formed by adiabatic decompression of

432 BAB-like mantle metasomatized by slab-derived fluids. These observations raise a fundamental

433 question: were SEMFR lavas produced by seafloor spreading in the backarc basin or in the

434 forearc? The southernmost Mariana convergent margin has reorganized rapidly since its collision 435 with the Caroline Ridge, suggesting that SEMFR lavas were produced by different geological 436 settings that what exists today. From the location of SEMFR adjacent to the trench, it is clear that 437 these lavas formed in the forearc. We propose a geodynamic model for the southernmost Mariana 
438 arc, in which SEMFR formed to accommodate opening of the southernmost Mariana Trough

439 (Fig. 9A, B and Fig. 10A-C). Rupturing the forearc lithosphere allowed asthenospheric mantle to

440 flow into the forearc and to melt by adiabatic decompression under hydrous conditions $2.7-3.7$

441 Ma ago; and origin of SEMFR mantle (i.e. from the backarc basin, the arc or a slab window) is

442 still under investigation. Some SEMFR melts picked up fragments of pre-existing forearc mantle

443 during ascent, demonstrating that SEMFR lavas formed long after subduction initiation. Post-

444 magmatic activity (<2.7 Ma ago) shapes the S. Mariana forearc lithosphere (Fig. 9C) and formed

445 the NNW-SSE trending rifts of SEMFR, as we know it today (Fig. 9D and Fig. 10D).

\section{Conclusions}

448 Two important conclusions can be drawn from this study: i) SEMFR magmas formed by

449 adiabatic decompression in the southernmost IBM forearc, usually underlain by cold,

450 serpentinized harzburgitic mantle that rarely melts (Reagan et al., 2010); and ii) SEMFR lavas

451 were produced by melting of fertile asthenospheric mantle metasomatized by slab-derived fluids,

452 long after subduction initiation, allowing development of a forearc lithosphere. Our results show

453 that the southernmost Mariana forearc stretched to accommodate opening of the Mariana Trough

454 to form the SEMFR, allowing hydrated, asthenospheric mantle to flow into the forearc and to

455 produce new oceanic crust $\sim 2.7-3.7$ Ma ago. SEMFR lavas formed by adiabatic decompression

456 of depleted backarc mantle at $~ 30 \pm 6.6 \mathrm{~km}$ depth and $1224 \pm 40^{\circ} \mathrm{C}$. SEMFR at 2.7-3.7 Ma was

457 likely a ridge-like spreading center, where the slab-derived fluids enhanced mantle melting

458 beneath the forearc. Today, SEMFR is no longer magmatically active and amagmatic extension

459 shapes its morphology. 


\section{Acknowledgements}

461 We thank JAMSTEC for providing Kaiko samples and related videos, Teruaki Ishii, Stuart

462 Murchison, Katsuyoshi Michibayashi, Warren Lieu, Susumu Umino and two anonymous

463 reviewers for their help and their insightful comments that improved this manuscript. Many

464 thanks to the R/V Yokosuka crew for their efforts work during YK08-08 Leg 2 and YK10-12

465 cruises. This research was supported by NSF grant 0961352 to RJS. This is UTD Geosciences

466 Contribution \# 1246. 


\section{References}

468
ARAI S. 1994. Characterization of spinel peridotites by olivine-spinel compositional relationships: Review and interpretation. Chemical Geology 113, 191-204.

ARCULUS R. J. 2003. Use and abuse of the terms calcalkaline and calcalkalic. Journal of petrology 44, 929-935.

AREVALO JR. R. \& MCDONOUGH W. F. 2010. Chemical variations and regional diversity observed in MORB. Chemical Geology 271, 70-85.

BAKER E. T., EMBLEY R. W., WALKER S. L. et al. 2008. Hydrothermal activity and volcano distribution along the Mariana arc. Journal of Geophysical Research 113, B08S09, DOI: 10.1029/2005GC000948.

BECKER N. C. 2005. Recent volcanic and tectonic evolution of the southern Mariana arc. $P h D$ thesis, pp. 166, University of Hawai'i, Hawai'i.

BECKER N. C., FRYER P. \& MOORE G. F. 2010. Malaguana-Gadao Ridge: Identification and implications of a magma chamber reflector in the southern Mariana Trough. Geochemistry Geophysics Geosystems 11, Q04X13, DOI: 10.1029/2009GC002719.

BIRD P. 2003. An updated digital model of plate boundaries. Geochemistry Geophysics Geosystems 4, 1027, DOI:10.1029/2001GC000252.

BLOOMER S. H. \& HAWKINS J. W. 1983. Gabbroic and ultramafic rocks from the Mariana Trench: An island arc ophiolite. In Hayes D. E. (ed.) The Tectonic and Geologic Evolution of Southeast Asian Seas and Islands: Part 2. American Geophysical Union, Geophysical Monograph Series 27, pp. 294-317, Washington, D.C.

DICKINSON W. R. 1975. Potash-Depth (K-h) Relations in Continental Margin and IntraOceanic Magmatic Arcs. Geology 3, 53-56.

FRYER P. 1993. The relationship between tectonic deformation, volcanism, and fluid venting in the southeastern Mariana convergent plate margin. Proceedings of Jamstec, Symposium on deep sea research 9, 161-179.

FRYER P., BECKER N., APPELGATE B., MARTINEZ F., EDWARDS M. \& FRYER G. 2003. Why is the Challenger Deep so deep? Earth and Planetary Science Letters 211, 259-269.

FRYER P., FUJIMOTO H., SEKINE M. et al. 1998. Volcanoes of the southwestern extension of the active Mariana island arc : new swath-mapping and geochemical studies. Island Arc 7, 596-607.

FUNICIELLO F., FACCENNA C., GIARDINI D. \& REGENAUER-LIEB K. 2003. Dynamics of retreating slabs: 2. Insights from three-dimensional laboratory experiments. Journal of Geophysical Research 108, 2207, DOI: 10.1029/2001JB000896. 
FUNICIELLO F., MORONI M., PIROMALLO C., FACCENNA C., CENEDESE A. \& BUI H.

502

503

504

505

506

507

508

509

510

511

512

513

514

515

516

517

518

519

520

521

522

523

524

525

526

527

528

529

530

531

532

533

534

535

536 537

A. 2006. Mapping mantle flow during retreating subduction: Laboratory models analyzed by feature tracking. Journal of Geophysical Research 111, B03402, DOI: 10.1029/2005JB003792.

GAMO T., MASUDA H., YAMANAKA T. et al. 2004. Discovery of a new hydrothermal venting site in the southernmost Mariana Arc : Al-rich hydrothermal plumes and white smoker activity associated with biogenic methane. Geochemical Journal 38, 527-534.

GARDNER J. V. 2006. Law of the Sea Cruise to Map the Western Insular Margin and 2500-m Isobath of Guam and the Northern Mariana Islands. Cruise report. Center for Coastal and Ocean Mapping (CCOM)/Joint Hydrographic Center (JHC), University of New Hampshire (UNH), Durham, NH.

GARDNER J. V. 2007. U.S. Law of the Sea Cruise to Map the Western Insular Margin and 2500-m Isobath of Guam and the Northern Mariana Islands. Cruise report. Center for Coastal and Ocean Mapping (CCOM)/Joint Hydrographic Center (JHC), University of New Hampshire (UNH), Durham, NH.

GARDNER J. V. 2010. U.S. Law of the Sea cruises to map sections of the Mariana Trench and the eastern and southern insular margins of Guam and the Northern Mariana Islands. Cruise report. Center for Coastal and Ocean Mapping (CCOM)/Joint Hydrographic Center (JHC), University of New Hampshire (UNH), Durham, NH.

GARDNER J. V. \& ARMSTRONG A. A. 2011. The Mariana Trench: A new view based on multibeam echosounding. American Geophysical Union, Fall Meeting 2011, abstract \#OS13B-1517, San Fransisco.

GRIBBLE R. F., STERN R. J., BLOOMER S. H., STÜBEN D., O'HEARN T. \& NEWMAN S. 1996. MORB mantle and subduction components interact to generate basalts in the southern Mariana Trough back-arc basin. Geochimica et Cosmochimica Acta 60, 21532166.

GVIRTZMAN Z. \& STERN R. J. 2004. Bathymetry of Mariana trench-arc system and formation of the Challenger Deep as a consequence of weak plate coupling. Tectonics 23, TC2011, DOI: $10.1029 / 2003 t c 001581$.

HAWKINS J. W., LONSDALE P. F., MACDOUGALL J. D. \& VOLPE A. M. 1990. Petrology of the axial ridge of the Mariana Trough backarc spreading center. Earth and Planetary Science Letters 100, 226-250.

HULME S. M., WHEAT C. G., FRYER P. \& MOTTL M. J. 2010. Pore water chemistry of the Mariana serpentinite mud volcanoes: A window to the seismogenic zone. Geochemistry Geophysics Geosystems 11, Q01X09, DOI:10.1029/2009gc002674.

HYNDMAN R. D. \& PEACOCK S. M. 2003. Serpentinization of the forearc mantle. Earth and Planetary Science Letters 212, 417-432. 
538

539

540

541

542

543

544

545

546

547

548

549

550

551

552

553

554

555

556

557

558

559

560

561

562

563

564

565

566

567

568

569

570

571

ISHIZUKA O., TANI K., REAGAN M. K. et al. 2011. The timescales of subduction initiation and subsequent evolution of an oceanic island arc. Earth and Planetary Science Letters 306, 229-240.

JAQUES A. L. \& GREEN D. H. 1980. Anhydrous melting of peridotite at $0-15 \mathrm{~Kb}$ pressure and the genesis of tholeiitic basalts. Contributions to Mineralogy and Petrology 73, 287-310.

KAKEGAWA T., UTSUMI M. \& MARUMO K. 2008. Geochemistry of Sulfide Chimneys and Basement Pillow Lavas at the Southern Mariana Trough $\left(12.55^{\circ} \mathrm{N}\right.$ and $\left.12.58^{\circ} \mathrm{N}\right)$. Resource Geology 58, 249-266.

KATO T., BEAVAN J., MATSUSHIMA T., KOTAKE Y., CAMACHO J. T. \& NAKAO S. 2003. Geodetic evidence of back arc spreading in the Mariana trough. Geophysical Research Letters 30, 1625, DOI:10.1029/2002GL016757.

KATZ R. F., SPIEGELMAN M. \& LANGMUIR C. H. 2003. A new parameterization of hydrous mantle melting. Geochemistry Geophysics Geosystems 4, 1073, DOI: 10.1029/2002GC000433.

KELLEY K. A. \& COTTRELL E. 2009. Water and the Oxidation State of Subduction Zone Magmas. Science 325, 605-607.

KELLEY K. A., PLANK T., GROVE T. L., STOLPER E. M., NEWMAN S. \& HAURI E. 2006. Mantle melting as a function of water content beneath back-arc basins. Journal of Geophysical Research 111, B09208, DOI: 10.1029/2005jb003732.

KELLEY K. A., PLANK T., LUDDEN J. \& STAUDIGEL H. 2003. Composition of altered oceanic crust at ODP Sites 801 and 1149. Geochemistry Geophysics Geosystems 4, 8910, DOI: $10.1029 / 2002 \mathrm{GC} 000435$.

KELLEY K. A., PLANK T., NEWMAN S. et al. 2010. Mantle Melting as a Function of Water Content beneath the Mariana Arc. Journal of Petrology 51, 1711-1738.

KIMURA J.-I. \& STERN R. J. 2008. Neogene Volcanism of the Japan Island Arc: The K-h Relationship Revisited. In Spencer J.E. and Titley S.R. (ed.) Ores and Orogenesis; Circum-Pacific Tectonics, Geologic Evolution, and Ore Deposits. Geological Society, Digest 22, pp., 187-202, Arizona.

KLEIN E. M. \& LANGMUIR C. H. 1987. Global correlations of ocean ridge basalt chemistry with axial depth and crustal thickness. Journal of Geophysical Research 92, 8089-8115.

LALLEMAND S. 2001. La subduction océanique, Gordon and Breach Science Publishers, Amsterdam.

LE BAS M. J. 2000. IUGS Reclassification of the High-Mg and Picritic Volcanic Rocks. Journal of Petrology 41, 1467-1470. 
572

573

574

575

576

577

578

579

580

581

582

583

584

585

586

587

588

589

590

591

592

593

594

595

596

597

598

599

600

601

602

603

604

605

606

LEE C.-T. A., LUFFI P., PLANK T., DALTON H. \& LEEMAN W. P. 2009. Constraints on the depths and temperatures of basaltic magma generation on Earth and other terrestrial planets using new thermobarometers for mafic magmas. Earth and Planetary Science Letters 279, 20-33.

MARTINEZ F., FRYER P. \& BECKER N. 2000. Geophysical characteristics of the southern Mariana Trough, $11^{\circ} 50^{\prime} \mathrm{N}-13^{\circ} 40^{\prime} \mathrm{N}$. Journal of Geophysical Research 105, 16,591-16,607.

MARTINEZ F. \& STERN R. J. 2009. The Southern Mariana Convergent Margin: A PreOphiolite Analogue. American Geophysical Union, Fall Meeting 2009, abstract\#T33D05, San Fransisco.

MICHIBAYASHI K., OHARA Y., STERN R. J. et al. 2009. Peridotites from a ductile shear zone within back-arc lithospheric mantle, southern Mariana Trench: Results of a Shinkai 6500 dive. Geochemistry Geophysics Geosystems 10, Q05X06, DOI: 10.1029/2008GC002197.

MILLER M. S., GORBATOV A. \& KENNETT B. L. N. 2006a. Three-dimensional visualization of a near-vertical slab tear beneath the southern Mariana arc. Geochemistry Geophysics Geosystems 7, Q06012, DOI:10.1029/2005gc001110.

MILLER M. S., KENNETT B. L. N. \& TOY V. G. 2006b. Spatial and temporal evolution of the subducting Pacific plate structure along the western Pacific margin. Journal of Geophysical Research 111, B02401, DOI: 10.1029/2005jb003705.

MIYASHIRO A. 1974. Volcanic rock series in island arcs and active continental margins. American Journal of Science 274, 321-355.

MOTTL M. J., WHEAT C. G., FRYER P., GHARIB J. \& MARTIN J. B. 2004. Chemistry of springs across the Mariana forearc shows progressive devolatilization of the subducting plate. Geochimica et Cosmochimica Acta 68, 4915-4933.

OHARA Y. \& ISHII T. 1998. Peridotites from the southern Mariana forearc: Heterogeneous fluid supply in mantle wedge. Island Arc 7, 541-558.

OHARA Y., REAGAN M., ISHII T. et al. 2008. R/V Yokosuka YK08-08 LEG 2 cruise report: Structure and origin of the Mariana forearc and implications for the origin of the continental crust : A Shinkai 6500 study of he southern Mariana forearc. JAMSTEC, Yokosuka.

OHARA Y., REAGAN M., MICHIBAYASHI K. et al. 2010. R/V Yokosuka YK10-12 cruise report: Composition, tectonic and structure of the Mariana forearc. JAMSTEC, Yokosuka.

OHARA Y., STERN R. J., ISHII T., YURIMOTO H. \& YAMAZAKI T. 2002. Peridotites from the Mariana Trough: first look at the mantle beneath an active back-arc basin. Contributions to Mineralogy and Petrology 143, 1-18. 
607

608

609

610

611

612

613

614

615

616

617

618

619

620

621

622

623

624

625

626

627

628

629

630

631

632

633

634

635

636

637

638

639

640

641

642

PARKINSON I. J. \& PEARCE J. A. 1998. Peridotites from the Izu-Bonin-Mariana Forearc (ODP Leg 125): Evidence for Mantle Melting and Melt-Mantle Interaction in a SupraSubduction Zone Setting. Journal of petrology 39, 1577-1618.

PEARCE J. A., STERN R. J., BLOOMER S. H. \& FRYER P. 2005. Geochemical mapping of the Mariana arc-basin system : Implications for the nature and distribution of subduction components. Geochemistry Geophysics Geosystems 6, 27, DOI:10.1029/2004GC000895.

PECCERILLO A. \& TAYLOR S. R. 1976. Geochemistry of Eocene calcalkaline volcanic rocks from the Kastamonu Area, Northern Turkey. Contributions to Mineralogy and Petrology $58,63-81$.

REAGAN M. K., ISHIZUKA O., STERN R. J. et al. 2010. Fore-arc basalts and subduction initiation in the Izu-Bonin-Mariana system. Geochemistry Geophysics Geosystems 11, Q03X12, DOI: 10.1029/2009GC002871.

ROEDER P. L. \& EMSLIE R. F. 1970. Olivine-liquid equilibrium. Contributions to Mineralogy and Petrology 29, 275-289.

RÜPKE L. H., MORGAN J. P., HORT M. \& CONNOLLY J. A. D. 2004. Serpentine and the subduction zone water cycle. Earth and Planetary Science Letters 223, 17-34.

SATO H. \& ISHII T. 2011. Petrology and Mineralogy of Mantle Peridotites from the Southern Marianas. In Ogawa Y., Anma R. and Dilek Y. (ed.) Accretionary Prisms and Convergent Margin Tectonics in the Northwest Pacific Basin, Modern Approaches in Solid Earth Sciences. Springer 8, pp. 129-147, Houten, Netherlands.

SAVOV I. P., RYAN J. G., D'ANTONIO M. \& FRYER P. 2007. Shallow slab fluid release across and along the Mariana arc-basin system: Insights from geochemistry of serpentinized peridotites from the Mariana fore arc. Journal of Geophysical Research B09205, DOI: 10.1029/2006JB004749.

SAVOV I. P., RYAN J. G., D'ANTONIO M., KELLEY K. \& MATTIE P. 2005. Geochemistry of serpentinized peridotites from the Mariana Forearc Conical Seamount, ODP Leg 125: Implications for the elemental recycling at subduction zones. Geochemistry Geophysics Geosystems 6, Q04J15, DOI: 10.1029/2004GC000777.

SCHELLART W. P., FREEMAN J., STEGMAN D. R., MORESI L. \& MAY D. 2007. Evolution and diversity of subduction zones controlled by slab width. Nature 446, 308-311.

SHAW A. M., HAURI E. H., FISCHER T. P., HILTON D. R. \& KELLEY K. A. 2008. Hydrogen isotopes in Mariana arc melt inclusions: Implications for subduction dehydration and the deep-Earth water cycle. Earth and Planetary Science Letters 275, 138-145.

SHEN Y. \& FORSYTH D. W. 1995. Geochemical constraints on initial and final depths of melting beneath mid-ocean ridges. Journal of Geophysical Research, 100 2211-2237. 
643

SMITH W. H. F. \& WESSEL P. 1990. Gridding with continuous curvature splines in tension. Geophysics 55, 293-305.

STERN R. J. 2002. Subduction Zones. Reviews of Geophysics 40, 37, DOI:10.1029/2001RG000108.

STERN R. J. 2010. The anatomy and ontogeny of modern intra-oceanic arc systems. In Kusky T.M., Zhai M.-G. and Xiao W. (ed.) The Evolving Continents: Understanding Processes of Continental Growth. Geological Society of London, Special Publication 338, pp.7-34, London, U.K.

STERN R. J. \& BLOOMER S. H. 1992. Subduction zone infancy: Examples from the Eocene Izu-Bonin-Mariana and Jurassic California arcs. Geological Society of America Bulletin $104,1621-1636$.

STERN R. J., FOUCH M. \& KLEMPERER S. L. 2003. An Overview of the Izu-Bonin-Mariana Subduction Factory. In Eiler J. and Hirschmann M.. (ed.) Inside the subduction factory. American Geophysical Union, Geophysical Monograph 138, pp. 175-222, Whashington, D.C.

STERN R. J., KOHUT E., BLOOMER S. H., LEYBOURNE M., FOUCH M. \& VERVOORT J. 2006. Subduction factory processes beneath the Guguan cross-chain, Mariana Arc: no role for sediments, are serpentinites important? Contributions to Mineralogy and Petrology $151,202-221$.

STERN R. J., TAMURA Y., MASUDA H. et al. 2013. How the Mariana Volcanic Arc ends in the south. Island Arc 22, 133-148.

TAYLOR B. \& MARTINEZ F. 2003. Back-arc basin basalt systematics. Earth and Planetary Science Letters 210, 481-497.

TIBI R., WIENS D. A. \& YUAN X. 2008. Seismic evidence for widespread serpentinized forearc mantle along the Mariana convergence margin. Geophysical Research Letters 35, L13303, DOI: $10.1029 / 2008 \mathrm{gl} 1034163$.

VAN KEKEN P. E., KIEFER B. \& PEACOCK S. M. 2002. High-resolution models of subduction zones: Implications for mineral dehydration reactions and the transport of water into the deep mantle. Geochemistry Geophysics Geosystems 3, 1056, DOI:10.1029/2001GC000256.

WADA I., RYCHERT C. A. \& WANG K. 2011. Sharp thermal transition in the forearc mantle wedge as a consequence of nonlinear mantle wedge flow. Geophysical Research Letters 38, L13308, DOI: 10.1029/2011g1047705.

WADE J. A., PLANK T., STERN R. J. et al. 2005. The may 2003 eruption of Anatahan volcano, Mariana Islands: Geochemical evolution of a silicic island-arc volcano. Journal of Volcanology and Geothermal Research 146, 139-170. 
679

680

681

682

683

684

685

686

687

688

689

690

691

692

693

694

695

696

697

698

699

700

701

702

703

704

705

706

707

708

709

710

711

712

713

714

715

WALLACE L. M., MC CAFFREY R., BEAVAN J. \& ELLIS S. 2005. Rapid microplate rotations and backarc rifting at the transition between collision and subduction. Geology $33,857-860$.

WESSEL P. \& SMITH W. H. F. 1995a. New version of the Generic Mapping Tools released. EOS Transactions American Geophysical Union 76, 329, AGU, Washington, D.C.

WESSEL P. \& SMITH W. H. F. 1995b. New version of the Generic Mapping Tools released. EOS Transactions American Geophysical Union electromic supplement [online]. [Cited 17 July 2012]. Available from http://www.agu.org/eos_elec/951546.html, AGU, Washington, D.C.

WESSEL P. \& SMITH W. H. F. 1998. New, improved version of Generic Mapping Tools released. EOS Transactions American Geophysical Union 79, 579, AGU, Washington, D.C.

WHEAT C. G., FRYER P., FISHER A. T. et al. 2008. Borehole observations of fluid flow from South Chamorro Seamount, an active serpentinite mud volcano in the Mariana forearc. Earth and Planetary Science Letters 267, 401-409.

\section{Tables}

Table 1: Major (wt\%) element compositions of SEMFR lavas. Mg\# [= atomic $\left(\mathrm{Mg}^{2+} * 100\right)$ / $\left.\left(\mathrm{Mg}^{2+}+\mathrm{Fe}^{2+}\right)\right]$ was calculated assuming all the iron is $\mathrm{Fe}^{2+}$ on anhydrous basis. Primitive samples with $7 \mathrm{wt} \% \leq \mathrm{MgO}<8 \mathrm{wt} \%$ were corrected on anhydrous basis by using the equations of Klein and Langmuir (1987) for $\mathrm{Na}_{8}$ and $\mathrm{Fe}_{8}$, and Taylor and Martinez (2003) for $\mathrm{Ti}_{8}$. See text for details. Sample numbers with * have no major element data reported; minor element data will be reported elsewhere. fg: fine-grained, ol: olivine, pl: plagioclase, cpx: clinopyroxene.

Table 2: Overview of mean mineral compositions in basalts from each dive in the SEMFR. $n$ : is the total number of analyses performed in one sample, $s$ : is the number of minerals analyzed in each sample, c: core, $\mathrm{m}:$ mantle, st : sieve texture, $\mathrm{r}$ : rim, gr: groundmass, ${ }^{*}$ : minerals in 1235 R12 observed in the microcrystallized basalt, while the other 1235-R12 analyses refer to minerals in the diabasic xenolith. Numbers in italics represent reverse zoning. Bold numbers represent minerals with oscillatory zoning. NA: Not analyzed. MGR: Malaguana-Gadao Ridge, SEMFR: S.E. Mariana Forearc Rift.

\section{Figure Captions}

Fig. 1: Locality maps. A) Izu-Bonin-Mariana intraoceanic arc system. The IBM magmatic arc generally lies $\sim 200 \mathrm{~km}$ from the trench and the Mariana Trough backarc basin spreading center generally lies $\sim 300 \mathrm{~km}$ from the trench. The arrows represent Pacific-Mariana convergence vectors from Kato et al. (2003). Yellow box shows the area of B. B) Bathymetric map of the southernmost Mariana arc-backarc basin system. Southward, the magmatic arc (white line) 
approaches the Malaguana-Gadao spreading ridge, both of which lie unusually close ( 110 km) to the trench. Location of the Malaguana-Gadao spreading ridge is from Martinez et al. (2000).

718 Filled colored circles show locations of YK06-12, YK08-08 Leg 2 and YK10-12 Shinkai dives

719 and YK08-08 Leg 2 YKDT deep-tow cameras; the small circles show the locations of dredge site D27 (Bloomer \& Hawkins, 1983), Shinkai 6500 dives158 and 159 (Fryer, 1993) and dredge sites KH98-1D1 and KH98-1D2 (Sato \& Ishii, 2011); triangles show the locations of KR00-03 Leg 2 Kaiko dives in Toto caldera and Malaguana-Gadao Ridge. Note that Kaiko dive 164 is near the magma chamber (MC) identified by Becker et al. (2010). The white box shows the approximate region encompassed by SEMFR. The dashed white line shows the position of the W. Santa Rosa Bank (WSRB) Fault which separates older rocks of the Santa Rosa Bank (SRB) from the SEMFR younger rocks. The red numbers are ${ }^{40} \mathrm{Ar}-{ }^{39} \mathrm{Ar}$ radiometric ages. Map generated with GMT (Smith \& Wessel, 1990, Wessel \& Smith, 1995b, Wessel \& Smith, 1998, Wessel \& Smith, 1995a) by using a compilation from the University of New Hampshire / Center for Coastal and Ocean Mapping / Joint Hydrographic Center (Gardner, 2006, Gardner, 2007, Gardner, 2010). C) Sidescan sonar (HMR1) image of the S. Mariana convergent margin (Fryer et al., 2003) with the location of traverses by JAMSTEC submersibles during YK06-12, YK08-08 Leg 2, YK10-12 and KR00-03 Leg 2 cruises. Dark areas have high backscatter, whitish corresponds to low backscatter. The SEMFR, the Malaguana-Gadao Ridge (MGR) and Toto caldera are dominated by high backscatter, indicating that the oceanic crust or lightly sedimented basement is exposed. White dashed line denotes SEMFR axial deeps, ridges lie between the valleys. Black arrows show the opening of SEMFR (Martinez \& Stern, 2009). FNVC (Fina-Nagu Volcanic Chain) represents extinct arc volcanoes.

Fig. 2: Typical bottom profiles of SEMFR encountered during seafloor traverses. A) near the trench axis (Shinkai 6500 dive 1230) and B) near the Fina-Nagu Volcanic Chain (YKDT-87). Near the trench, SEMFR flanks are dominated by steep talus slopes of lava fragments with few exposures of tilted and faulted lava flows. Talus and outcrops are covered by thin pelagic sediment. Near the Fina-Nagu Volcanic Chain (FNVC), SEMFR relief is smoother with betterpreserved pillow lava outcrops covered by thin sediment. Photographs of the typical seafloor observed near the trench $(C, D)$ and near the FNVC (E). Black star in B) shows the beginning of YKDT deep-tow camera dredging.

Fig. 3: Photomicrographs of SEMFR lavas and fine gabbro. A) Typical microporphyritic olivine - clinopyroxene basalt (sample 1230-R2) with microlitic groundmass and microphenocrysts of plagioclase (pl) and clinopyroxene (cpx). B) Fine-grained diabase xenolith (sample 1235-12) hosted by microcrystalline basalt (finer grained part to left). The diabase contains Mg-rich olivine (Fo $\left.{ }_{89}\right)$, Mg-rich clinopyroxene ( $\left.\mathrm{Mg} \# \geq 80\right)$ and normally zoned Ca-rich plagioclase $(\geq 0.1 \mathrm{~mm})$. In contrast, the basaltic host is more fractionated, with Fe-rich olivine (Fo85-86) and Mg-rich clinopyroxene microphenocrysts $(\geq 0.1 \mathrm{~mm})$. Clinopyroxene in the groundmass $(<0.1 \mathrm{~mm})$ are Mg-poor and coexist with Ca-poor plagioclase microlites. Clinopyroxenes in the diabase exhibit oscillatory and reverse zoning. The boundary between the two textural realms is straight, suggesting that basalt magma picked up solidified diabase. See Supporting Information S4 for more details. C) Olivine - clinopyroxene basalt from YKDT-88 containing large olivine xenocrysts surrounded by olivine-rich groundmass. D) Photomicrograph of cryptocrystalline plagioclase basalt from Shinkai dive 1235 (sample 1235-R8) hosting an amphibole gabbro xenolith (chl: chlorite, amph: amphibole). The contact between gabbro and basalt is an irregular chilled margin, suggesting that the basalt picked up solid pieces of gabbro. A second chilled 
margin is observed inside the basalt, suggesting multiple magmatic injections in the basalt. E) Photomicrograph of plagioclase (pl) xenocryst observed in the Shinkai dive 1230 (sample 1230R17). The core of the plagioclase is well-preserved and exhibits $A_{91-92}$ content. The mantle exhibits $\mathrm{An}_{80-89}$ and is mostly resorbed (sieve-texture) due to the interaction plagioclase - melt. The rim is well-preserved and is $\mathrm{An}_{83-88}$. Plagioclase microlites have lower An content (An $<80$ $\%$ ). Larger, $\mathrm{Mg}$-rich clinopyroxenes (cpx) occur near the An-rich plagioclase xenocrysts ( $\mathrm{Mg} \#=$ 86 - 88), while the clinopyroxenes microlites exhibit higher range in Mg\# (74 - 88). Such An-

Fig. 4: Major element compositional characteristics of SEMFR, MGR, Eocene forearc basalts (FABs; Reagan et al., 2010), S. Mariana Arc lavas (SMArc: $13^{\circ} 10^{\prime} \mathrm{N}-11^{\circ} \mathrm{N}$ ) which include Toto caldera lavas. All data recalculated to $100 \%$ anhydrous. A) Potash-silica diagram (Peccerillo \& Taylor, 1976), showing that SEMFR lavas are low-K basalts to medium-K basaltic andesites. The grey field represents Mariana Trough BAB lavas (Gribble et al., 1996, Hawkins et al., 1990, Kelley \& Cottrell, 2009, Pearce et al., 2005) and the hatched field represents Mariana Arc lavas (Kelley \& Cottrell, 2009, Kelley et al., 2010, Pearce et al., 2005, Shaw et al., 2008, Stern et al., 2006, Wade et al., 2005). The small grey triangles are Malaguana-Gadao Ridge (MGR) data from Kakegawa et al. (2008) and Pearce et al. (2005). The small black triangles are data from SMA volcanoes (Kakegawa et al., 2008, Stern et al., 2013). Larger grey triangles denote MGR and larger black triangles denote Toto samples reported in this manuscript. The field for boninites is from Reagan et al. (2010). Note that SEMFR lavas mostly plot in field of Mariana Trough BAB lavas. B) $\mathrm{FeO} * / \mathrm{MgO}$ vs $\mathrm{SiO}_{2}$ diagram for medium-Fe, medium-Fe, high-Fe discrimination (Arculus, 2003); green line discriminates between tholeiitic and calk-alkaline lavas (Miyashiro, 1974). C) $\mathrm{Mg} \#$ vs $\mathrm{SiO}_{2}$ and D) $\left.\left.\mathrm{CaO}, \mathrm{E}\right) \mathrm{Al}_{2} \mathrm{O}_{3}, \mathrm{~F}\right) \mathrm{FeO}^{*}$ plotted against $\mathrm{MgO}$ for SEMFR, MGR, and Toto caldera. When plagioclase starts crystallizing, it produces a hinge in the liquid line of descent (LLD) of $\mathrm{Al}_{2} \mathrm{O}_{3}$. The hinge in $\mathrm{Al}_{2} \mathrm{O}_{3}$ is observed at $\mathrm{MgO}=6 \mathrm{wt} \%$; and the kink in $\mathrm{CaO}$ and $\mathrm{FeO}^{*}$ is observed at $\mathrm{MgO} \sim 7 \mathrm{wt} \%$. Therefore. primitive lavas are identified with $\mathrm{MgO} \geq 7$ $\mathrm{wt} \%$, following the method of Kelley et al. (2010). Arrows represent fractionation trends. Ol : olivine, pl : plagioclase, cpx : clinopyroxene. We used the same method as for SEMFR lavas $(\mathrm{MgO} \geq 7 \mathrm{wt} \%)$ to filter the Mariana arc and Mariana Trough lavas.

Fig. 5: Variation of A) olivine Fo and B) clinopyroxene Mg\# composition with whole rock Mg\#. C) Variation of An content of plagioclase core with whole rock $\mathrm{CaO}$ (wt\%) content. Olivine, clinopyroxene and plagioclase are mostly in equilibrium with their host rock. Fractional crystallization (grey arrow) removes Mg-rich minerals from the residual melt which precipitates increasingly Fe-rich minerals. The olivine-liquid equilibrium line is calculated from experimental data of Roeder and Emslie (1970) with $\mathrm{K}_{\mathrm{D}}$ olivine - melt $=0.3$ and $\mathrm{Fe}^{3+} / \mathrm{Fe}_{\mathrm{T}}=0.17$ (Kelley \& Cottrell, 2009). D) Olivine - Spinel Mantle Array (OSMA) diagram of Arai (1994). Cr\# of spinel inclusions and Fo content of host olivine xenocrysts in Shinkai dive 1096 upper series (blue star) and in YKDT-88 lavas (pink stars) plot within OSMA. Cr\# are means for each spinel inclusion and reported with the Fo content of their olivine host. Their Cr\# $\geq 50$ is similar to that of the southern Mariana forearc peridotite (Ohara \& Ishii, 1998); whereas BAB peridotites have Cr\# < 30 (Ohara et al., 2002). SEMFR peridotites (Michibayashi et al., 2009, Sato \& Ishii, 2011) have $\mathrm{Cr} \#$ and Fo contents intermediate between southern Mariana forearc peridotites and Mariana Trough BAB peridotites (Ohara et al., 2002). E) Large xenocryst of anhedral olivine (ol) with Fo90-92 hosting chromium spinel (sp) and melt inclusions (MI) from sample YKDT88-R2. 
810 Fig. 6: The ${ }^{40} \mathrm{Ar} /{ }^{39} \mathrm{Ar}$ age spectra with ${ }^{36} \mathrm{Ar} /{ }^{40} \mathrm{Ar} v{ }^{39} \mathrm{Ar} /{ }^{40} \mathrm{Ar}$ plot for samples from the SEMFR. Percentage of ${ }^{39} \mathrm{Ar}$ released during analysis is also reported. versus $\mathrm{Ti}_{8} . \mathrm{Na}_{8}$ and $\mathrm{Ti}_{8}$ are proxies for the fraction of mantle that is melted, $\mathrm{Fe}_{8}$ is a proxy for the depth of mantle melting (Klein \& Langmuir, 1987, Pearce et al., 2005), and $\mathrm{K}_{2} \mathrm{O} / \mathrm{TiO}_{2}$ is a proxy for the subduction input. The grey field represents Mariana Trough BAB lavas (Gribble et al., 1996, Hawkins et al., 1990, Kelley \& Cottrell, 2009, Pearce et al., 2005) and the hatched field represents Mariana arc lavas (Kelley \& Cottrell, 2009, Kelley et al., 2010, Pearce et al., 2005, Shaw et al., 2008, Stern et al., 2006, Wade et al., 2005). Primitive lavas from the Mariana Trough and the Mariana arc were filtered as SEMFR lavas $(\mathrm{MgO} \geq 7 \mathrm{wt} \%)$ for consistency. The FABs field is from Reagan et al. (2010). The negative correlation of $\mathrm{Na}_{8}$ with $\mathrm{Fe}_{8}$ of $\mathrm{N}-\mathrm{MORBs}$ (grey arrow; Arevalo Jr. \& McDonough, 2010) shows that more magma is produced when melting begins deeper; while in subduction-related lavas, more melting is produced shallower. SEMFR lavas have $\mathrm{Na}_{8}$ and $\mathrm{Ti}_{8}$ contents slightly varying with $\mathrm{Fe}_{8}$ content, indicating homogeneous degree of mantle melting.

Fig. 8: A) Composition ranges for coexisting olivine Fo - plagioclase An in intraoceanic arc lavas (blue field) and BABB (red outline) after Stern et al. (2006). Arc basalts have more calcic plagioclase in equilibrium with more Fe-rich olivine compared to MORB (short dashed outline), OIB (long dashed outline), and BABB. The plagioclase-olivine relationships of SEMFR lavas generally plot in the overlap between the BABB and the arc composition fields. The black triangle denotes a Toto caldera sample. B) P-T conditions of mantle-melt equilibration estimated by using the procedure of Lee et al. (2009) for SEMFR primitive lavas with $\mathrm{MgO} \geq 7 \mathrm{wt} \%$. Also shown are Mariana Trough basaltic glasses (Gribble et al., 1996, Kelley \& Cottrell, 2009), and the Mariana arc melt inclusions with analyzed water contents (Kelley et al., 2010, Shaw et al., 2008). The solidus is from Katz et al. (2003). We used $\mathrm{Fe}^{3+} / \mathrm{Fet}=0.17$ for SEMFR and Mariana Trough BABBs, $\mathrm{Fe}^{3+} / \mathrm{Fet}=0.25$ for Mariana arc lavas (Kelley \& Cottrell, 2009) and Fo 90 for the equilibrium mantle. We used the same method as for SEMFR lavas ( $\mathrm{MgO} \geq 7 \mathrm{wt} \%)$ to filter the Mariana arc and Mariana Trough glass for consistency. The pink field represents the slab depth beneath SEMFR ( $\leq 30 \mathrm{~km}-100 \mathrm{~km}$ depth; Becker et al., 2005).

851

852 Spreading of the Mariana Trough rifts the arc lithosphere (in orange) and forms SEMFR by stretching the forearc crust (in yellow) $\sim 2.7-3.7 \mathrm{Ma}$ ago. We speculate that SEMFR is a spreading center with intense magmatic activity. C) Post-magmatic deformation of SEMFR occurred $<2.7$ Ma ago, and intensely deformed the Eocene forearc crust. D) Today, SEMFR is no longer magmatically active and amagmatic extension dominates the rift. Eocene forearc is eroded with opening of the S. Mariana Trough; and actual position of the forearc is based on R/V Yokosuka YK08-08 Leg 2 and YK10-12 cruise reports (Ohara et al., 2010, Ohara et al., 2008). The red box highlights the area of Fig. 10. lithospheric section of Gvirtzman \& Stern (2004) and the tomographic images of Miller et al. (2006a). The cross section is drawn from the area highlighted by a red box in Fig. 9. BAB lithos.: backarc basin lithosphere. A) Opening of the S. MarianaTrough, the Malaguana-Gadao Ridge (MGR), strectches the pre-existing Eocene forearc lithosphere $\sim 5 \mathrm{Ma}$ ago. B) Rupturing of the 
857 forearc allow mantle melting, creating new SEMFR oceanic crust $\sim 2.7-3.7 \mathrm{Ma}$ ago. The red

858 line shows the location of the cross section of SEMFR shown in C. C) Continuous dehydration

859 of the shallow downgoing slab controlled SEMFR magmatic activity, and SEMFR had ridge

860 morphology 2.7 - 3.7 Ma ago. D) Today, post-magmatic rifting dominates SEMFR.

861

\section{Supporting Information:}

863 Supporting Information S1: Description of the dives

864 Fig. S1.1: Cross-sections of SEMFR rifts 1, 2 and 3 from the trench

865 Fig. S1.2: Dive tracks of Shinkai dives 1096, 1230 and 1235 and deep tow camera 82

866 Fig. S1.3: Dive tracks of YKDT 85, 86, 87 and 88.

867 Fig. S1.4: Dive tracks of Shinkai dive 973 from YK06-12 cruise report and Kaiko dive 163 from

868 KR00-03 Leg 2 cruise report

869 Fig. S1.5: Interpreted bathymetric profile of the eastern flank of rift 1 traversed during Shinkai

870 dive 1096

871 Fig. S1.6: Interpreted bathymetric profile of the eastern flank of rift 2 traversed during Shinkai

872 dive 1230

873 Fig. S1.7: Interpreted bathymetric profile of the eastern flank of rift 3 traversed during Shinkai

874 dive 1235.

875 Fig. S1.8: Interpreted bathymetric profile of the eastern flank of rift 1 traversed during Shinkai

876 dive 973

877 Fig. S1.9: Interpreted bathymetric profile of the summit of ridge on the eastern side of rift 3

878 traversed during YKDT-85

879 Fig. S1.10: Interpreted bathymetric profile of the eastern flank of ridge of rift 3 (central part of

880 SEMFR) traversed during YKDT-86

881 Fig. S1.11: Interpreted bathymetric profile of YKDT-82, performed on the summit of a ridge

882 between rifts 2 and 3

883 Fig. S1.12: Interpreted bathymetric profile of the axial valley of rift 3 traversed during YKDT-87

884 Fig. S1.13: Interpreted bathymetric profile of the eastern flank of ridge of rift 2 performed during

885 YKDT-88

886 Fig. S1.14: Interpreted bathymetric profile of Toto caldera performed during Kaiko dive 163

887 Fig. S1.15: Interpreted bathymetric profile along the Malaguana-Gadao Ridge performed during

888 Kaiko dive 164 , near the $13^{\circ} \mathrm{N}$ magmatic chamber

889 Table S1.1: Longitude and latitude of the dives in the SEMFR, MGR and Toto caldera with their

890 depth and trench distance

891 Table S1.2: Variation of the width and depth $(\mathrm{km})$ of the three SEMFR rifts along axis.

892

893

894

895

896

897

898

899 Supporting Information S4: Petrographic description and mineralogy of the samples

900 Fig. S4.1: SEMFR mineral compositions in clinopyroxene, plagioclase and olivine 
901 Table S4.1: Representative mean clinopyroxene composition

902 Table S4.2: Representative mean plagioclase composition

903 Table S4.3: Representative mean olivine composition

904 Table S4.4: Representative mean spinel composition

905

906 Supporting Information S5: Correlation between mineral abundances and whole rock chemistry

907 Fig. S5.1: Plot showing the correlation between mineral abundances and whole rock composition.

908 A) The olivine proportions are positively correlated to the whole-rock $\mathrm{Mg \#}$

909

910 Supporting Information S6: Effects of the variations of the Fo content on the P-T conditions of

911 SEMFR mantle melting

912 